\title{
Genetic and metabolic diversity of Arctic bacterioplankton during the post-spring phytoplankton bloom in Disko Bay, western Greenland
}

\author{
Lone Frette, Anne Winding, Niels Kroer* \\ Department of Environmental Chemistry and Microbiology, National Environmental Research Institute, Aarhus University, \\ Frederiksborgvej 399, 4000 Roskilde, Denmark
}

\begin{abstract}
Changes in the genetic and metabolic diversity of the bacterioplankton in Disko Bay, western Greenland, were followed during the post-spring phytoplankton bloom. Samples were taken at different depths every 2 to $3 \mathrm{~d}$ from 1 to 23 June 2001. The highest bacterial abundance was found at the depth of the fluorescence maximum (FM). Average cell numbers at FM were around $6 \times$ $10^{5}$ cells $\mathrm{ml}^{-1}$, but numbers were highly variable. Immediately following a rapid decline in the phytoplankton biomass from 31 to $8 \mathrm{mg} \mathrm{chl} \mathrm{a} \mathrm{m}^{-3}$, a peak in numbers of culturable bacteria was observed reaching $3 \times 10^{4} \mathrm{CFU} \mathrm{ml}^{-1}$. Concomitant with the changes in phytoplankton biomass and bacterial culturability, the genetic diversity of the bacterioplankton communities changed as assessed by DGGE. At FM, DGGE fingerprints shifted between 6 and 8 June; however, they returned to the initial profile between 10 and 14 June. Similarly, successional shifts in the diversity of the culturable bacteria were observed as the populations before and after the peak in CFUs were significantly different. Accompanying the changes in genetic diversity, the metabolic diversity of the bacterial communities shifted and the communities became adapted to growth on refractory carbon sources such as cellulose and xylan. Our investigation thus demonstrates intimate links between phytoplankton and bacterioplankton and that the spring phytoplankton bloom strongly affects the genetic diversity and functional characteristics of the heterotrophic bacterial communities in Disko Bay.
\end{abstract}

KEY WORDS: Bacterioplankton $\cdot$ Arctic $\cdot$ Genetic diversity $\cdot$ Metabolic diversity $\cdot$ Spring bloom

\section{INTRODUCTION}

Coastal Arctic ecosystems are a focus of major environmental concern due to the potential impacts of global warming on the northern polar region. Temperature changes may affect the thickness and extent of the sea ice and hence indirectly affect the timing and duration of phytoplankton production (Carmack et al. 2004). Since Arctic heterotrophic bacterioplankton are considered to be important consumers of dissolved organic matter (Allen et al. 2002, Howard-Jones et al. 2002), they are likely to play an important role in the response of Arctic coastal ecosystems to shifts in the development of the spring phytoplankton bloom.
The diversity and structure of marine bacterioplankton communities in Arctic waters have not been investigated to the same extent as in temperate waters (Malmstrom et al. 2007, Alonso-Sáez et al. 2008). The relatively few studies that have been carried out - primarily by sequencing of cloned fragments of $16 \mathrm{~S}$ rRNA genes and fluorescent in situ hybridization-have identified several bacterial phyla. These include the Cytophaga-Flavobacterium-Bacteroidetes group bacteria, Alpha-, Beta-, Gamma-, Delta- and Epsilonproteobacteria, Verrucomicrobia, Actinobacteria and green nonsulfur bacteria (Bano \& Hollibaugh 2002, Elifantz et al. 2007, Malmstrom et al. 2007, Alonso-Sáez et al. 2008). Generally, Cytophaga-like bacteria and Alpha- 
and Gammaproteobacteria seem to be dominant members of the pelagic microbial communities, although large geographical differences are apparent. Also, Archaea have been observed (Wells \& Deming 2003, Kirchman et al. 2007, Alonso-Sáez et al. 2008).

Our knowledge on the coupling between the annual Arctic spring phytoplankton bloom and the structure of the heterotrophic bacterial communities is limited. Müller-Niklas \& Herndl (1996) studied bacterioplankton abundance and production during a decaying phytoplankton bloom off Hayes Island in the FranzJoseph Land archipelago. They found an increase in both bacterial abundance and bacterial production simultaneously with a significant decrease in phytoplankton biomass and primary production. Based on analysis of cloned sequences of 16S rRNA genes from the Arctic Ocean, Bano \& Hollibaugh (2002) found seasonal variability in the phylogenetic composition of the microbial assemblages and suggested that this was a reflection of the annual cycle of the primary production. Similarly, Yager et al. (2001) found changes in DGGE banding patterns through different stages of a coastal Alaska spring phytoplankton bloom, and suggested that substrate and virioplankton interactions controlled the microbial community.

The pelagic food web in Disko Bay has been extensively studied (e.g. Møller et al. 2003, Juul-Pedersen et al. 2006). A tight coupling exists between the phytoplankton, the mesozooplankton and the pool of nutrients. The break-up of the sea ice typically sets the stage for the initiation of the spring bloom. The bloom lasts a few weeks until depletion of nitrogen in the euphotic zone (Juul-Pedersen et al. 2006). Concomitant with the onset of the bloom, a standing stock of overwintering Calanus copepods ascends from the deep waters and exploits the developing bloom. These copepods have been shown to be responsible for the grazing of more than half of the primary production per day (Nielsen \& Hansen 1995). In turn, up to almost $60 \%$ of the carbon cleared by the copepods may be lost as dissolved organic carbon (DOC) due to sloppy feeding and leakage from newly expelled fecal pellets (Møller et al. 2003). The released DOC feeds the microbial loop and an estimated 30 to $50 \%$ of the primary production may be directed through the bacterioplankton trophic level (Nielsen \& Hansen 1999), resulting in bacterial produc-

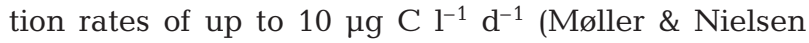
2000 ), of which an estimated 0.5 to $3 \% \mathrm{~d}^{-1}$ is grazed by bacterivorous protists (Nielsen \& Hansen 1999).

While the pelagic carbon cycling and transfer of carbon from phytoplankton to the higher trophic levels and the microbial loop in Disko Bay are relatively well investigated, very little is known about the genetic and functional structure of the heterotrophic bacterial communities. Only scant information is available on the spatial and temporal fluctuations in the community structure, and it is not known to what extent a succession in the phytoplanktom bloom is accompanied by changes in the genetic and metabolic diversity of the bacterioplankton.

The aim of the present study was to investigate bacterioplankton dynamics during the degradation phase of the diatom spring bloom in Disko Bay. We hypothesized that successional changes in the phytoplankton bloom would be reflected in the diversity and functional characteristics of the heterotrophic bacterial communities. We addressed the hypothesis by relating a diverse set of bacterial parameters, including bacterial density (direct counts), numbers and diversity of CFUs, DGGE fingerprints, EcoPlate utilization patterns and hydrolysis of different polymeric substrates, to phytoplankton pigment analyses.

\section{MATERIALS AND METHODS}

Study site and sampling scheme. The investigation was conducted in June 2001 at the mouth of Disko Bay, western Greenland, approximately 1 nautical mile off Qeqertarsuaq (69 $\left.15^{\prime} \mathrm{N}, 5^{\circ} 33^{\prime} \mathrm{W}\right)$. The sampling station was visited 10 times.

Disko Bay is influenced by melt water and icebergs from an outlet glacier, resulting in a stratified water column from the time of the ice break and throughout the summer (Andersen 1981). The western part of the bay is also influenced by the Baffin Current and the West Greenland Current (Buch 2000). Surface velocities have been estimated to range between 0.05 and $0.11 \mathrm{~m} \mathrm{~s}^{-1}$ in summer (Buch 2000, Juul-Pedersen et al. 2006). If an average velocity of $0.08 \mathrm{~m} \mathrm{~s}^{-1}$ is assumed, then the samples taken during the $23 \mathrm{~d}$ investigation were representative of a water mass spanning a distance of about $160 \mathrm{~km}$.

Vertical profiles of water temperature and fluorescence were recorded down to $200 \mathrm{~m}$ as described in Juul-Pedersen et al. (2006). At each visit, water was collected at $5 \mathrm{~m}$ depth and at the fluorescence maximum (FM; 25 to $50 \mathrm{~m}$ depth). On 8 occasions, additional samples were taken at 50 and $100 \mathrm{~m}$ depth. On 11 June the FM and $50 \mathrm{~m}$ samples coincided. After collection, water samples were kept in dark and cold conditions during transport back to the laboratory.

Pigment analyses and bacterial abundance. Chlorophyll a (chl a) and phaeopigments were measured from $100 \mathrm{ml}$ duplicate subsamples filtered into Whatman GF/F filters and then extracted in 96\% ethanol (Juul-Pedersen et al. 2006).

Samples for bacterial total counts were preserved with buffered formaldehyde (1\% final concentration). Numbers of cells were determined by a method 
adapted after del Giorgio et al. (1996). Essentially, $2 \mu \mathrm{l}$ SYTO 13 (Molecular Probes Europe) were added to a $0.5 \mathrm{ml}$ sample and cells were enumerated on a FACSCalibur ${ }^{\mathrm{TM}}$ flow cytometer (Becton Dickinson) on the basis of their green fluorescence and sideward scatter. A known concentration of fluorescent AlignFlow beads (2.5 $\mathrm{\mu m}$ in diameter, Molecular Probes) was added to each sample to allow calculation of cell numbers from relative numbers of cells and beads. Cells with a high nucleic acid content (HNA cells) were discriminated from cells with a low nucleic acid content (LNA cells) as described by Lebaron et al. (2001).

Numbers of CFUs and isolation of pure cultures. Numbers of CFUs in samples from FM were determined by plate spreading on ZoBell agar plates (Zobell 1946). Plates contained 5.0 g Bacto peptone (Difco), $1.0 \mathrm{~g}$ yeast extract (Difco), $0.015 \mathrm{~g} \mathrm{FePO}_{4} \cdot 4 \mathrm{H}_{2} \mathrm{O}$ (Riedelde Haën) and $15 \mathrm{~g}$ agar (Difco) per liter of $0.2 \mu \mathrm{m}$ filtered (Sartorius $0.2 \mu \mathrm{m}$ cellulose acetate filters) Disko Bay water. Plates were incubated at 10 to $13^{\circ} \mathrm{C}$ and counted daily until no new colonies were observed. The slightly elevated incubation temperature relative to the in situ temperature (see Fig. 1A) may potentially have resulted in an underestimation of the number of culturable psychrophilic bacteria; however, it was chosen for practical reasons to insure that visible colonies were obtained during the investigation.

Thirty randomly chosen isolates per sampling time were streaked on new ZoBell agar plates. The random isolation procedure was chosen to specifically select for the abundant culturable bacteria and to provide an estimate of their relative abundance. Isolates were kept at 3 to $5^{\circ} \mathrm{C}$ for a maximum of $9 \mathrm{~d}$ before they were frozen at $-80^{\circ} \mathrm{C}$ in $50 \%$ (v/v) glycerol in liquid ZoBell medium. Samples taken on 1 and 4 June only gave rise to a total of 13 and 20 colonies, respectively, and these were all isolated.

Identification of isolated bacteria. Isolated bacteria were classified on the basis of colony shape, color and size and grouped according to their internal transcribed 16S-23S rDNA spacer (ITS) regions. DNA was extracted by transferring colonies with a sterile toothpick into $1.5 \mathrm{ml}$ safe-lock Eppendorf tubes containing $150 \mu \mathrm{l} 0.04 \mathrm{M}$ Tris-acetate EDTA buffer (Sigma). The tubes were vortexed and boiled for $10 \mathrm{~min}$. After centrifugation $\left(15000 \times g, 10 \mathrm{~min}, 4^{\circ} \mathrm{C}\right)$, supernatants containing the DNA were transferred to new $1.5 \mathrm{ml}$ Eppendorf tubes and stored at $4{ }^{\circ} \mathrm{C}$. DNA coding for the ITS region was amplified by PCR using the primers ITS-16S-1392-S-15 and ITS-23S-206-A-21 (Willumsen et al. 2005). Each PCR tube contained a total volume of $25 \mu \mathrm{l}$ and consisted of $1 \mu \mathrm{l}$ of bacterial DNA, $0.5 \mu \mathrm{M}$ of each primer, $250 \mu \mathrm{M}$ of each dNTP (Roche, cat. no. 1277049), $2.5 \mu \mathrm{l} 10 \times$ PCR Reaction Buffer (Roche, cat. no. 1271318), $0.5 \mathrm{mM} \mathrm{MgCl}_{2}$ (Roche, cat. no. 1699113) and $0.5 \mathrm{U}$ Taq DNA polymerase (Roche, cat. no. 1435094). After PCR (30 cycles of $30 \mathrm{~s}$ at $94^{\circ} \mathrm{C}, 60 \mathrm{~s}$ at $55^{\circ} \mathrm{C}, 2$ min at $72^{\circ} \mathrm{C}$ and final cooling at $4^{\circ} \mathrm{C}$ ), products were detected by electrophoresis $(100 \mathrm{~V}, 2 \mathrm{~h})$ on a $3 \%$ (w/v) NuSieve agarose gel (FMS BioProducts) in $1 \times$ Tris-Borate-EDTA buffer (TBE; Sharlau Chemie). The gels were stained with $0.001 \%$ (w/v) ethidium bromide (Bio-Rad) and photographed. The lengths of amplified products were estimated by comparison against DNA Molecular Weight Markers VI (Roche, cat. no. 1062590) and XIV (Roche, cat. no. 1721933). Isolates with identical band sizes were grouped together and band size matches verified on a new gel.

The 16S rDNA of one isolate from each of the different ITS groups was partially sequenced using primers SDBact0008aS20 (5'-AGA GTT TGA TC(AC) TGG CTC AG-3') and S*UNIV518aA18 (5'-GTA TTA CCG CGG CTG CTG-3') modified after Wilmotte et al. (1993). To avoid unspecific amplification and to ensure high product concentration, the annealing temperature was optimized for each isolate. The optimal annealing temperatures were $61^{\circ} \mathrm{C}$ (39 isolates), $58^{\circ} \mathrm{C}$ (5 isolates), and $72^{\circ} \mathrm{C}$ (4 isolates). After PCR ( 25 cycles of $30 \mathrm{~s}$ at $94^{\circ} \mathrm{C}, 30 \mathrm{~s}$ at $58 / 61 / 72^{\circ} \mathrm{C}, 2 \mathrm{~min}$ at $72^{\circ} \mathrm{C}$, and finally 6 min at $72^{\circ} \mathrm{C}$ followed by cooling at $4^{\circ} \mathrm{C}$ ), products were purified using the QIAquick PCR purification kit (Qiagen) following the manufacturer's instructions. Sequencing was performed by MWG Biotech (www.mwg-biotech.com) on an NEN Global IR ${ }^{2}$ DNA Sequencer (LI-COR) in one direction using the primer S*UNIV518aA18. Sequences were aligned against sequences found in GenBank by BLAST search.

DGGE. Molecular community fingerprints of the free-living bacterioplankton were obtained by DGGE essentially as described by Riemann \& Winding (2001). Water samples were filtered through $150 \mathrm{~mm}$ Whatman 3 filters $(6 \mu \mathrm{m})$ to exclude mitochondrial and chloroplast DNA. Subsamples of $200 \mathrm{ml}$ of the filtrate were filtered onto $0.2 \mu \mathrm{m}$ membrane filters $(25 \mathrm{~mm}$ diameter Supor®-200, Pall Sciences). Filters were frozen at $-20^{\circ} \mathrm{C}$ for a maximum of $34 \mathrm{~d}$ followed by freezing at $-80^{\circ} \mathrm{C}$ until DNA was extracted by a freezethaw-boiling protocol (Riemann \& Winding 2001). DNA in the resulting supernatant was precipitated with $1 / 4$ volume $10.5 \mathrm{M}$ sodium acetate and 3 volume $96 \%$ ethanol, washed with $70 \%$ ethanol and resuspended in $50 \mu \mathrm{l}$ Tris-EDTA. The primers GC341 F (Muyzer et al. 1993) and 907 R (Wilmotte et al. 1993) were used for amplification of $16 \mathrm{~S}$ rDNA. PCR reactions $(25 \mu \mathrm{l})$ contained $1 \mathrm{ng}$ of bacterial DNA, $0.5 \mu \mathrm{M}$ of each primer, $200 \mu \mathrm{M}$ of each dNTP, $2.5 \mu \mathrm{l} 10 \times$ PCR Reaction Buffer, $0.5 \mathrm{mM} \mathrm{MgCl}_{2}$ and $0.25 \mathrm{U}$ Taq DNA polymerase. After PCR $\left(5 \mathrm{~min}\right.$ at $94^{\circ} \mathrm{C}, 30$ cycles of $60 \mathrm{~s}$ at $94^{\circ} \mathrm{C}, 60 \mathrm{~s}$ at $65^{\circ} \mathrm{C}$ decreasing $1^{\circ} \mathrm{C}$ every 2 cycles to a final temperature of $56^{\circ} \mathrm{C}, 3 \mathrm{~min}$ at $72^{\circ} \mathrm{C}, 10 \mathrm{~min}$ at 
$72^{\circ} \mathrm{C}$ and final cooling at $4{ }^{\circ} \mathrm{C}$ ), the size and purity of the PCR products were verified by agarose gel electrophoresis. PCR products were quantified fluorometrically using the nucleic acid stain PicoGreen (Molecular Probes) prior to DGGE (Riemann \& Winding 2001). DGGE gels were silver stained and preserved according to Christoffersen et al. (2002).

Generally one filter was used for DGGE analysis at each sampling time and sampling depth; however, replicate (duplicate and/or triplicate) filters were run on the following occasions: $5 \mathrm{~m}$ (6, 10 and 23 June), FM (10, 14, 17 and 23 June), $50 \mathrm{~m}$ (6 and 10 June) and $100 \mathrm{~m} \mathrm{(14,17}$ and 23 June). Since DGGE is not strictly quantitative, only the number of bands and their position were recorded and used in the statistical analysis of the data.

Functional characterization of the bacterioplankton communities. Triplicate EcoPlates (Biolog) were inoculated with $150 \mu \mathrm{l}$ Whatman 3 filtrate per well and incubated for $8 \mathrm{~d}$ at 10 to $13^{\circ} \mathrm{C}$. Color development in the wells, caused by reduction of the tetrazolium dye, was scored (by eye) as either positive or negative.

Numbers of bacteria capable of hydrolyzing 5 different polymers were estimated by a most probable number procedure in microtitre plates with 8 replicates and 6 dilutions (6-fold). Whatman 3 filtrate $(40$ or $50 \mu l)$ served as inoculum in $0.2 \mu \mathrm{m}$ filtered seawater added to one of the following substrates: $0.2 \%(\mathrm{w} / \mathrm{v}) \mathrm{AZCL}$ (Azurine-Crosslinked)-casein (Megazyme), $0.2 \%$ (w/v) AZCL-amylose (Megazyme), 0.2\% (w/v) AZCLhe-cellulose (Megazyme), $0.2 \%$ (w/v) AZCL-xylan (Megazyme) or $0.2 \%(\mathrm{w} / \mathrm{v})$ starch (Sigma) in a total volume of 240 or $250 \mu l$. Plates were incubated for $38 \mathrm{~d}$. Development of blue color in wells containing the AZCL-linked substrates indicated hydrolysis of the substrate. Lugol's solution (Fluka Chemie; 2\% final concentration) was added to wells containing starch. Positive wells remained colorless; negative wells were colored red.

Functional characterization of isolated bacteria. The ability of the isolated bacteria to hydrolyze $0.2 \%$ (w/v) AZCL-casein, $0.1 \%(\mathrm{w} / \mathrm{v})$ AZCL-amylose, $0.1 \%$ (w/v) AZCL-galactomannan, 0.1\% (w/v) AZCL-hecellulose and $0.1 \%(\mathrm{w} / \mathrm{v})$ AZCL-xylan was tested on Zobell agar plates amended with $30 \mathrm{~g} \mathrm{l}^{-1}$ Sea Salts (Sigma) and the above substrates. Plates were incubated at $10^{\circ} \mathrm{C}$ until no further color reaction around colonies was observed.

Statistical analysis. Total bacterial numbers were compared pairwise using $t$-test $(\mathrm{p}<0.05)$. Principal component analysis (PCA), using SAS version 8 for Windows, was applied for the analysis of successional changes in community DGGE profiles, diversity of isolated bacteria (as determined by the length of the ITS region) and EcoPlate carbon respiration patterns. Differences along PCA axes were tested using ANOVA.
Accession numbers. Nucleotide sequences were filed in GenBank under the following accession numbers: FJ581923 to FJ581942 (Isolates 1 to 75), FH581960 (Isolate 78) and FJ581943 to FJ581959 (Isolates 85 to 223).

\section{RESULTS}

\section{Characteristics of the water body}

The water column was strongly stratified during most of June as a cold layer with temperatures below $0.5^{\circ} \mathrm{C}$ was located between the warmer surface and bottom water (Fig. 1A). The thickness of the cold layer decreased from about $50 \mathrm{~m}$ in early June to $0 \mathrm{~m}$ by the end of the month. Inorganic dissolved nutrients ranged from 0.04 to $0.5 \mu \mathrm{M} \mathrm{PO}_{4}{ }^{-}$and 0.0 to $4.4 \mu \mathrm{M}$ total $\mathrm{N}$ $\left(\mathrm{NO}_{3}{ }^{-}, \mathrm{NO}_{2}^{-}, \mathrm{NH}_{4}^{+}\right)$in and above the cold water layer, while concentrations below the cold water layer ranged from 0.6 to $1.2 \mu \mathrm{M} \mathrm{PO}_{4}{ }^{-}$and 0.0 to $13.1 \mu \mathrm{M}$ total N (T. G. Nielsen pers. comm.).

The phytoplankton spring bloom was already established when sampling started and was primarily associated with the cold intermediate water layer (Fig. 1B). The highest chl a concentration of $31.2 \pm 1.0 \mathrm{mg} \mathrm{m}^{-3}$ (mean $\pm \mathrm{SE}, \mathrm{n}=3$ ) was measured on 1 June. Maximal chl a concentrations rapidly declined to a level around 8 to $9 \mathrm{mg} \mathrm{m}^{-3}$ during the first week of June followed by a slower decline to approximately $2 \mathrm{mg} \mathrm{m}^{-3}$. A pattern similar to chl a was observed for phaeopigments (data
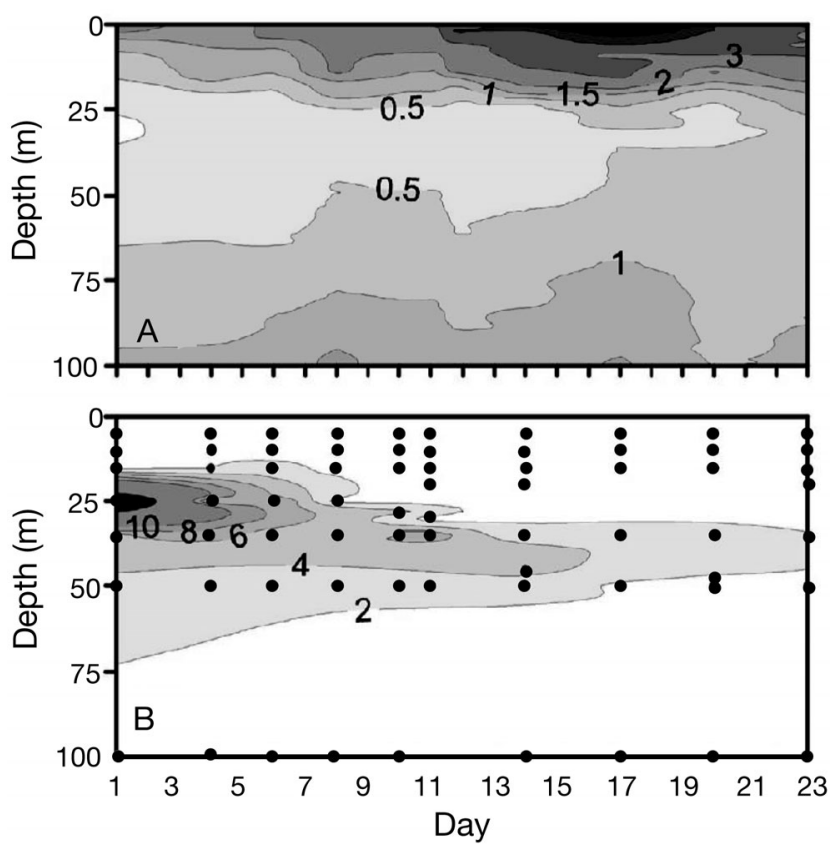

Fig. 1. Isolines of (A) temperature $\left({ }^{\circ} \mathrm{C}\right)$ and $(\mathrm{B})$ chl a concentrations $\left(\mathrm{mg} \mathrm{m}^{-3}\right)$. Points indicate sampling depths. Redrawn from Juul-Pedersen et al. (2006) 
not shown), with the highest concentration $(4.6 \pm 0.1$ $\mathrm{mg} \mathrm{m}^{-3}$ ) measured in the cold intermediate water layer on 1 June followed first by a strong and then by a more moderate decline.

\section{Bacterial abundance}

Bacterial abundance varied with respect to both depth and time (Fig. 2). The highest average and most rapidly fluctuating numbers of cells were observed at FM $\left(6.1 \times 10^{5}\right.$ cells ml $\left.{ }^{-1} ; \mathrm{p}<0.05\right)$. At $50 \mathrm{~m}$, peaks in mid-June $\left(5.8 \times 10^{5}\right.$ cells $\left.\mathrm{ml}^{-1}\right)$ and late June $\left(6.3 \times 10^{5}\right.$ cells $\mathrm{ml}^{-1}$ ) were observed. At 5 and $100 \mathrm{~m}$, numbers were relatively stable around 1.4 to 2.1 and 1.6 to $2.0 \times$ $10^{5}$ cells $\mathrm{ml}^{-1}$, respectively, although they increased to 7.1 and $3.4 \times 10^{5}$ cells $\mathrm{ml}^{-1}$, respectively, by the end of June (Fig. 2).

Numbers of HNA cells ranged from 50 to $81 \%(5 \mathrm{~m})$, 52 to $86 \%(\mathrm{FM}), 53$ to $72 \%(50 \mathrm{~m})$ and 60 to $75 \%$ $(100 \mathrm{~m})$ and explained most of the variation in the total number of bacteria (Fig. 2).
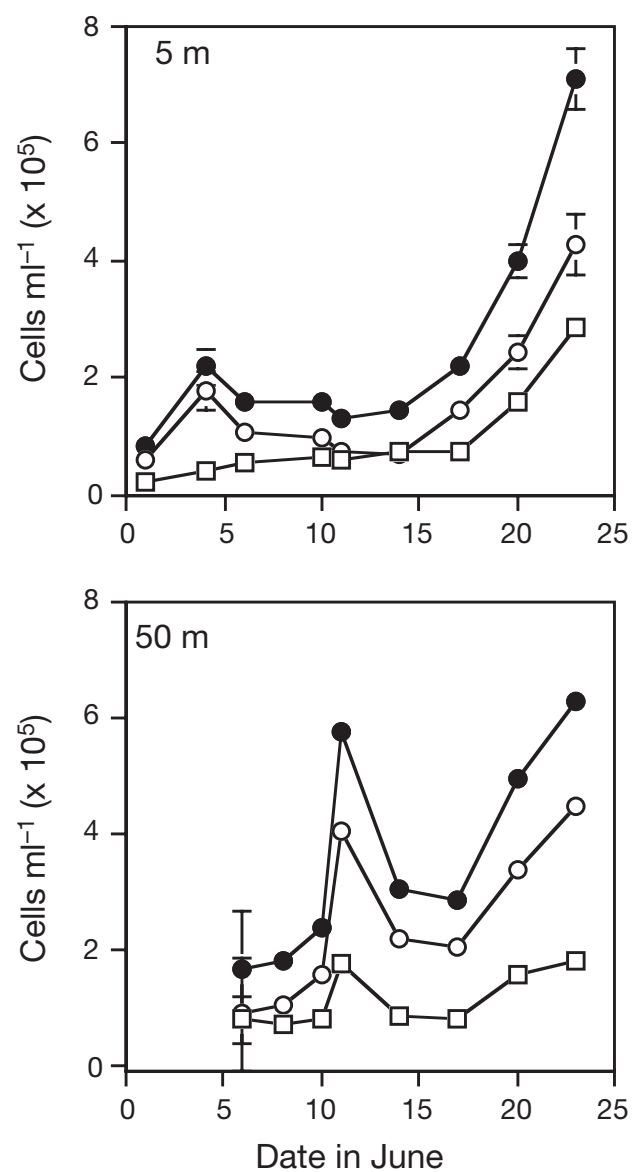

Numbers of CFUs at FM changed during the diatom bloom (Fig. 3A). On 1 and 4 June, values were $<40 \mathrm{CFU}$ $\mathrm{ml}^{-1}$, increasing to approximately $3 \times 10^{4} \mathrm{CFU} \mathrm{ml} \mathrm{m}^{-1}$ immediately after the initial rapid decline in chl a on 10 and 11 June. Between 14 and 23 June, CFU levels stabilised at around $3 \times 10^{3} \mathrm{CFU} \mathrm{ml}^{-1}$. Before the observed peak in numbers of CFUs (1 to 6 June), the population of culturable bacteria seemed to consist of slow growers, as up to 7 to $8 \mathrm{~d}$ of incubation was required before visible colonies appeared on the agar plates (Fig. 3B). After the CFU peak, on the other hand, visible colonies were detected after 2 to $4 \mathrm{~d}$, suggesting that these culturable bacteria were relatively fast growing (Fig. 3B).

\section{Bacterioplankton community fingerprinting}

The number of observed DGGE bands in each sample varied between 6 and 22, and a total of 27 different bands were observed.

The DGGE profiles of the free-living bacterioplankton varied both with respect to time and depth as
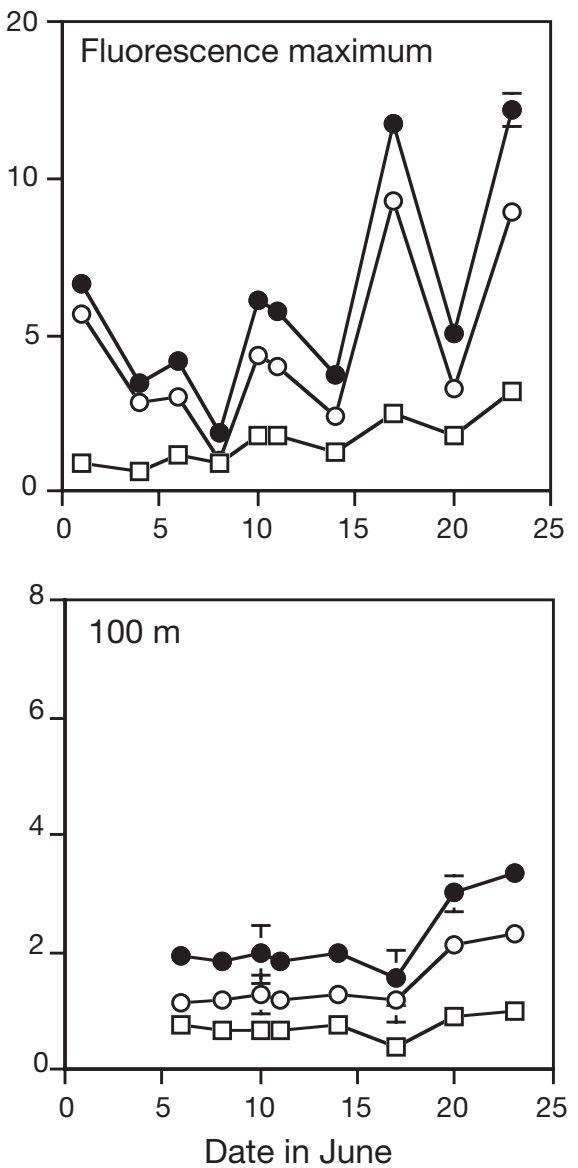

Fig. 2. Succession in bacterial numbers at $5 \mathrm{~m}$, fluorescence maximum, $50 \mathrm{~m}$ and $100 \mathrm{~m}$. (-): total counts; (O) high nucleic acid counts; $(\square)$ : low nucleic acid counts. Note the different scales on the $y$-axes. Error bars represent standard error of the mean $(n=3)$ 

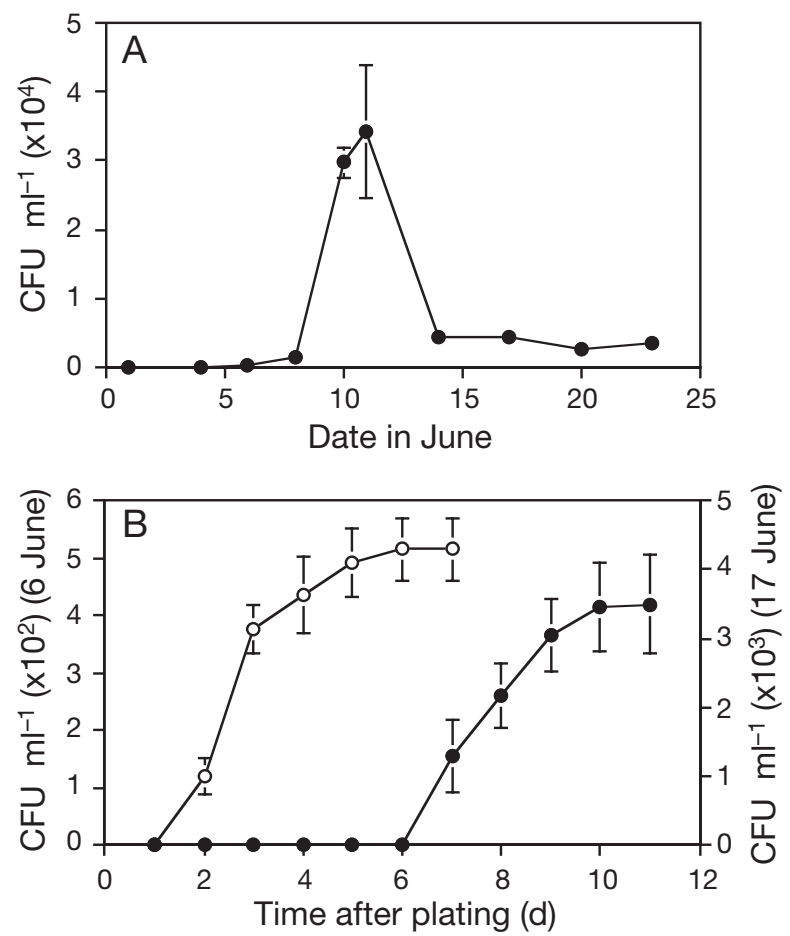

Fig. 3. (A) Changes in CFU numbers at the fluorescence maximum during the phytoplankton spring bloom, and (B) appearance of CFUs as function of incubation time on agar plates at 2 representative sampling times before (6 June, and after (17 June, O) the CFU peak on 10-11 June. Note the different scales on the $y$-axes in (B). Error bars represent standard error of the mean $(n=3)$

demonstrated by PCA (Fig. 4). The PC1 axis, which explained $34 \%$ of the variation, seemed primarily to describe temporal differences. Along this axis, the community profile on 8 to 11 June at $5 \mathrm{~m}$ depth clustered out from the other sampling days ( $p<0.001)$. At FM, the DGGE fingerprint changed between 6 and 8 June ( $p<0.001)$; however, it returned to the initial profile between 10 and 14 June. At $50 \mathrm{~m}$ depth, the profiles on 10 and 17 June were separated from the other sampling days, while at $100 \mathrm{~m}$ the community fingerprints on 17 to 23 June were clustered into a separate group ( $p<0.001$ ). PC2 explained $18 \%$ of the variation and appeared to describe differences in depth. Along the PC2 axis, FM was significantly different from 5, 50 and $100 \mathrm{~m}$ depth $(\mathrm{p}<0.001)$, whereas there was no significant difference between 50 and $100 \mathrm{~m}(\mathrm{p}=0.08)$.

\section{Diversity of culturable bacterioplankton}

A total of 11 different colony morphotypes were observed from the samples at fluorescence maximum. White round and transparent colonies of different size dominated. Only 3 colonies with a unique morphology

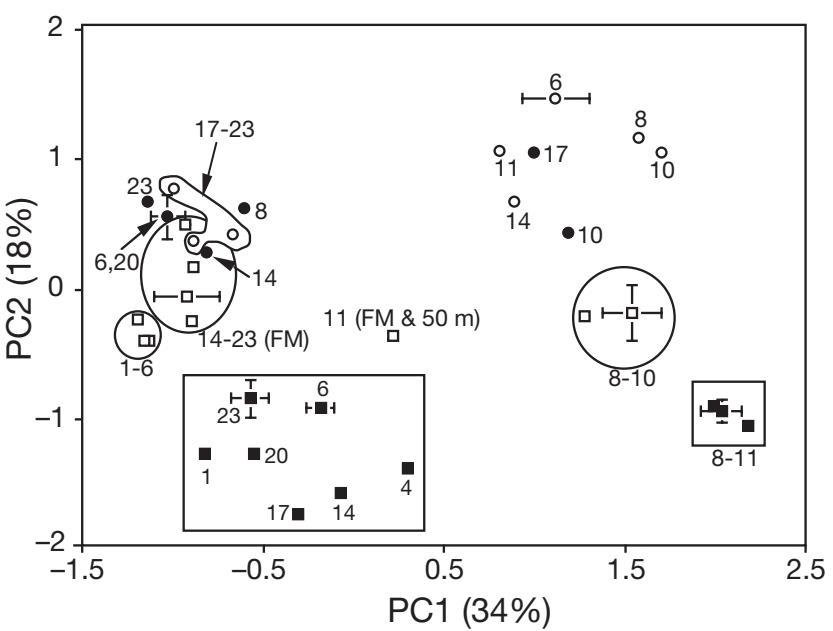

Fig. 4. Succession in DGGE community profiles. Data were analyzed by principal components analysis on the basis of the numbers of observed bands and their position in the gels. Percentages in parentheses on the axes indicate the variation explained by the 2 principal components. Samples taken at $5 \mathrm{~m}(\boldsymbol{\square})$, fluorescence maximum (FM; $\square), 50 \mathrm{~m} \mathrm{( \bullet )}$ and $100 \mathrm{~m}$ (O) are shown. Numbers indicate sampling date in June. Note that on 11 June, FM and $50 \mathrm{~m}$ coincided. Circles and squares enclosing data points highlight the seasonal shifts in bacterial community composition. Error bars represent the standard error of the mean of replicate filters used in the DGGE analysis

not seen among the randomly isolated colonies were found.

The bacterial isolates were divided into 40 different groups on basis of the length of the ITS regions. Some groups (e.g. Groups 21 to 23 and 35 to 37 ) were only occasionally observed, while others were found almost throughout the bloom (e.g. Groups 9, 11 and 28). Also, some groups were only represented by 1 or 2 isolates on individual sampling days (e.g. Groups 5 to 8 and 22 to 23), while others were represented by up to 21 isolates (Group 9). ITS Group 9 was most important both in terms of abundance and prevalence during the sampling period as it accounted for 65 out of the 245 isolated bacteria and was observed on all but the first 3 sampling days. It was not possible to amplify the ITS region of all of the isolated bacteria, as a few isolates were unable to resume growth after restreaking or freezer storage.

Successional shifts in the species composition of the isolated bacteria were observed. PCA of the occurrence of the 40 different ITS groups showed that bacteria isolated before and after the CFU peak (i.e. 1 to 6 and 14 to 23 June, respectively) clustered into separate groups (Fig. 5). The bacteria isolated during the peak (8 to 11 June) did not appear to cluster into a specific group (Fig. 5) and were, with the exception of 8 June, different from the bacteria isolated at the other sampling times. 


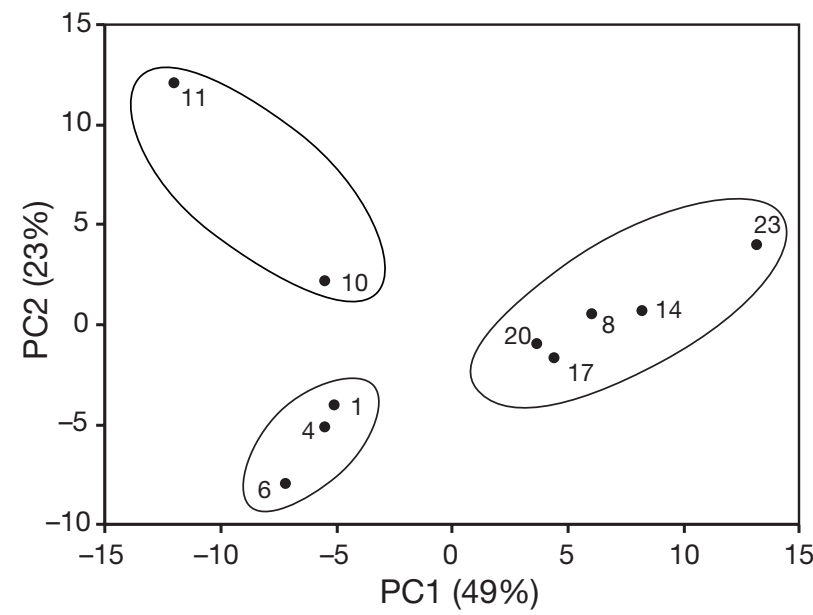

Fig. 5. Succession in the diversity of isolated bacteria (internal transcribed spacer [ITS] groups) at the fluorescence maximum assessed by principal component analysis (PCA). Percentages in parentheses indicate the variation explained by the 2 principal components. PCA was done on the basis of the numbers of isolates within each ITS group on the specific sampling dates. Numbers refer to sampling dates in June. Circles were added to highlight the seasonal shifts in the bacterial community composition

The 16S rDNA of one representative isolate of each ITS group was partially sequenced (no sequences were obtained for Groups 23 and 31). All sequenced isolates belonged to the Gammaproteobacteria (Table 1). Approximately $40 \%$ belonged to Alteromonadaceae, represented by the genera Alteromonas, Colwellia, Idiomarina, Pseudoalteromonas and Glaciecola. Another $34 \%$ of the isolates were closely related to the genus Pseudomonas, 16\% belonged to the genera Marinomonas (Oceanospirillaceae), while the remaining $10 \%$ of the identified isolates were Acinetobacter or Psychrobacter species within the Moraxellaceae. The marinomonads were only isolated between 8 and 14 June, i.e. when numbers of CFUs peaked (Fig. 3A).

\section{Bacterioplankton metabolic diversity}

The metabolic diversity of the $5 \mathrm{~m}$ and FM communities, as assessed by the EcoPlate metabolic fingerprints, changed during the diatom bloom, but no apparent temporal trends were observed (Fig. 6). Also, no differences between the 2 depths could be detected. Nineteen of the 31 different EcoPlate carbon sources were respired by the $5 \mathrm{~m}$ and FM communities. The maximal number of compounds respired at a given sampling day or community was 11 . On 3 occasions (1 June: $5 \mathrm{~m}$ and FM; 4 June 4: FM), none of the carbon sources were respired. Pyruvic acid methyl ester, Tween 80, Tween 40, glycogen and D-mannitol were the most frequently respired compounds. The remaining 14 compounds were respired on less than 3 occasions. The 12 carbon sources that were not respired by any of the bacterial communities during the sampling period included $\beta$-methyl-D-glucoside, N-acetyl-D-glucosamine, D-glucosaminic acid, glucose-1-phosphate, D-galactonic acid $\gamma$-lactone, 2hydroxy benzoic acid, $\gamma$-hydroxybutyric acid, itaconic acid, D-malic acid, L-arginine, phenylethylamine and putrescine.

The capacity of the bacterioplankton communities at $5 \mathrm{~m}$ and FM to hydrolyze polymeric substrates varied with time (Fig. 7). The communities primarily had the potential to hydrolyze casein and amylose. In the beginning of the sampling period ( 1 to 4 June), fewer than $3 \times 10^{2}$ cells $\mathrm{ml}^{-1}$ were able to hydrolyze the various substrates; however, from 6 to 11 June, the number of potential casein and amylose hydrolyzing bacteria increased to more than $3 \times 10^{5}$ cells $\mathrm{ml}^{-1}$. During the remaining part of the investigation, a variable number of bacteria were potential hydrolyzers of casein and amylose $\left(10^{3}\right.$ to $3 \times 10^{5}$ cells $\left.\mathrm{ml}^{-1}\right)$ and xylan $\left(2 \times 10^{2}\right.$ to $3 \times 10^{4}$ cells $\mathrm{ml}^{-1}$; Fig. 7). Cellulose and starch were only hydrolyzed by a small number of cells $\left(<2 \times 10^{2}\right.$ cells $\mathrm{ml}^{-1}$ ) at any given time and depth.

\section{Metabolic diversity of isolated bacteria}

The metabolic diversity of the isolated bacteria at FM (as assessed by their ability to hydrolyze casein, amylose, cellulose, galactomannan and xylan) changed during the phytoplankton bloom (Fig. 8).

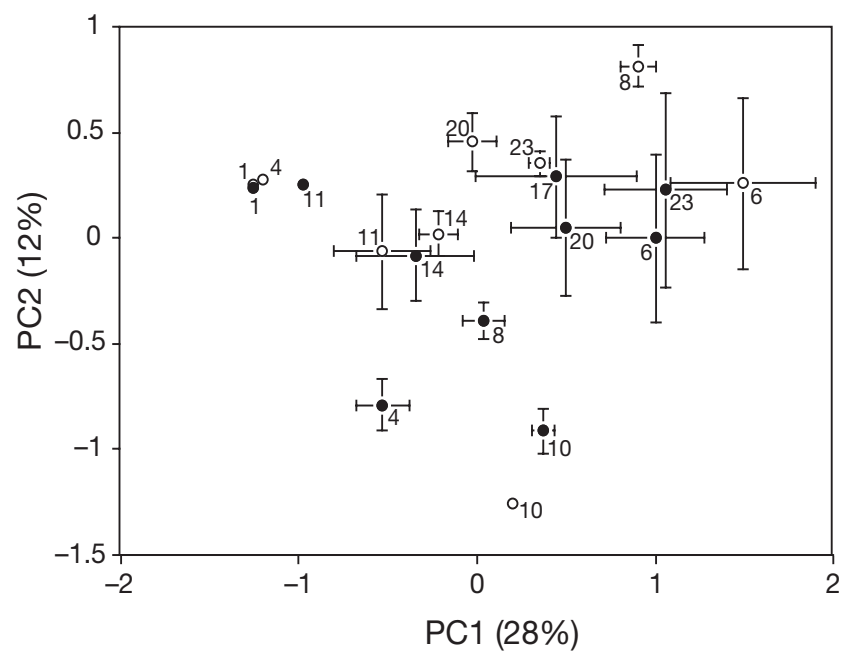

Fig. 6. Succession in EcoPlate carbon respiration patterns of the bacterial communities at $5 \mathrm{~m}$ depth $(\mathbf{0})$ and fluorescence maximum (O) assessed by principal component analysis. Percentages in parentheses indicate the variation explained by the 2 principal components. Numbers refer to sampling dates in June. Error bars represent the standard error of the mean of replicate EcoPlates 
Table 1. Cultivated nearest phylogentic neighbours of representative isolates of the ITS groups. nd = no data

\begin{tabular}{|c|c|c|c|c|c|c|c|}
\hline \multirow{2}{*}{$\begin{array}{l}\text { ITS } \\
\text { group }\end{array}$} & \multirow{2}{*}{$\begin{array}{l}\text { Sequenced } \\
\text { isolate }\end{array}$} & \multirow{2}{*}{$\begin{array}{l}\text { Size } \\
\text { (bp) }\end{array}$} & \multirow[b]{2}{*}{ Strain or clone } & \multicolumn{3}{|c|}{ st phylogenetic neighbour } & \multirow[b]{2}{*}{ Accession no } \\
\hline & & & & $\mathrm{bp} / \mathrm{bp}$ & $\%$ & Environment & \\
\hline 1 & 11 & 449 & Alteromonas macleodii & $438 / 447$ & 97 & Mediterranean Sea & Y18229 \\
\hline 2 & 18 & 470 & Pseudomonas tolaasii & $466 / 471$ & 98 & Plant pathogen & AF320989 \\
\hline 3 & 32 & 470 & Pseudomonas nitroreducens & $470 / 471$ & 99 & Freshwater wetland & AY297786 \\
\hline 4 & 61 & 470 & Pseudomonas tolaasii & $466 / 471$ & 98 & Plant pathogen & AF320989 \\
\hline 5 & 66 & 471 & Pseudoalteromonas sp. PRLIST2 & $471 / 471$ & 100 & Toxic dinoflagellate & Y15323 \\
\hline 6 & 69 & 469 & Pseudomonas putida & $468 / 469$ & 99 & nd & AF094746 \\
\hline 7 & 75 & 480 & Marinomonas sp. ACT1 & $479 / 480$ & 99 & Arctic Ocean & DQ676860 \\
\hline 8 & 78 & 463 & Pseudomonas sp. 4zhy & $447 / 447$ & 100 & Deep sea & EF107048 \\
\hline 9 & 70 & 428 & Pseudoalteromonas sp. BSi20062 & $428 / 428$ & 100 & Arctic sea ice & DQ007441 \\
\hline 10 & 181 & 446 & Pseudoalteromonas arctica & $444 / 446$ & 99 & Spitsbergen & DQ787199 \\
\hline 11 & 85 & 479 & Marinomonas sp. ACT1 & $478 / 480$ & 99 & Arctic Ocean & DQ676860 \\
\hline 12 & 93 & 475 & Marinomonas sp. clone F3C32 & $475 / 475$ & 100 & Antartica & AY697898 \\
\hline 14 & 128 & 471 & Marinomonas sp. W-3 & $462 / 472$ & 97 & Qingdao Fushan Bay & DQ923437 \\
\hline 15 & 129 & 475 & Pseudoalteromonas sp. S-2 & $475 / 475$ & 100 & Qingdao Fushan Bay & DQ978983 \\
\hline 16 & 141 & 440 & Marinomonas sp. W-3 & $431 / 434$ & 99 & Qingdao Fushan Bay & DQ923437 \\
\hline 17 & 166 & 476 & Marinomonas sp. NJ5 & $475 / 476$ & 99 & Psychrophilic & DQ191961 \\
\hline 18 & 178 & 468 & Pseudoalteromonas nigrifaciens & $465 / 468$ & 99 & Arctic & AY771728 \\
\hline 19 & 221 & 468 & Alteromonas macleodii & $468 / 469$ & 99 & Skagerrak & AF261044 \\
\hline 20 & 223 & 435 & Pseudoalteromonas sp. IE9 & $255 / 269$ & 96 & Sub-Antarctic sediment & EF089565 \\
\hline 21 & 1 & 452 & Glaciecola sp. BSi20138 & $451 / 452$ & 99 & Arctic sea ice & DQ492706 \\
\hline 22 & 4 & 394 & Glaciecola psychrophila & $390 / 393$ & 99 & Arctic sea ice & DQ007436 \\
\hline 23 & 5 & nd & & & & & \\
\hline 24 & 28 & 445 & Pseudomonas sp. & $441 / 441$ & 100 & Rainbow trout & AF451261 \\
\hline 25 & 29 & 475 & Acinetobacter sp. & $472 / 474$ & 99 & nd & Z93450 \\
\hline 26 & 31 & 471 & Pseudomonas sp. DVS6dlb & $471 / 473$ & 99 & Antarctica (soil) & AY864639 \\
\hline 27 & 45 & 342 & Pseudomonas sp. 130(2zx) & $334 / 340$ & 98 & Deep sea & AM409194 \\
\hline 28 & 79 & 472 & Pseudomonas sp. ARCTIC-P23 & $456 / 470$ & 97 & Arctic & AY573032 \\
\hline 29 & 116 & 475 & Pseudomonas sp. DVS6dlb & $471 / 472$ & 99 & Dry Valley, Antarctica & AY864639 \\
\hline 30 & 207 & 473 & Psychrobacter sp. 207(117zx) & $472 / 473$ & 99 & Deep sea & AM409197 \\
\hline 31 & 234 & nd & & & & & \\
\hline 32 & 123 & 408 & Pseudomonas sp. $\mathrm{Nj}-3$ & $408 / 408$ & 100 & Antarctica & AM396910 \\
\hline 33 & 22 & 444 & Pseudomonas sp. EP25 & $441 / 444$ & 99 & East Pacific & AM403527 \\
\hline 34 & 23 & 452 & Pseudomonas sp. clone cRI31d & $452 / 452$ & 100 & Plant (wild mustard) & AY364068 \\
\hline 35 & 6 & 482 & Colwellia sp. BSi20046 & $482 / 483$ & 99 & Arctic sea ice & DQ060392 \\
\hline 36 & 9 & 469 & Colwellia sp. ANT8279 & $460 / 470$ & 97 & nd & AY167268 \\
\hline 37 & 10 & 483 & Colwellia sp. BSi20003 & $477 / 478$ & 99 & Arctic sea ice & DQ060387 \\
\hline 38 & 55 & 471 & Acinetobacter johnsonii & $469 / 472$ & 99 & Sludge & AB099655 \\
\hline 39 & 120 & 461 & Psychrobacter sp. 207(117zx) & $454 / 462$ & 98 & Deep sea & AM409197 \\
\hline 40 & 210 & 481 & Idiomarina loihiensis L2TR & $480 / 481$ & 99 & nd & AE017340 \\
\hline 41 & 219 & 436 & Colwellia sp. U7 & $436 / 436$ & 100 & Sub-Antarctic seawater & AY100673 \\
\hline
\end{tabular}

None of the isolated bacteria showed hydrolytic affinity towards galactomannan. Between 1 and 6 June, $<15 \%$ of the bacteria showed hydrolytic activity. On 8 June, however, $78 \%$ of the isolates were able to hydrolyze one or more of the polymeric substrates. Of these, one-third was able to hydrolyze all 4 substrates (Fig. 8A). At the time of the highest CFU density (10 to 11 June), relatively few isolates $(<13 \%)$ were able to hydrolyze the investigated compounds (Fig. 8A). During the remainder of June, the fraction of isolates capable of hydrolyzing one or more of the substrates was relatively high and varied between 30 and $97 \%$ (Fig. 8A). Many of the isolates were able to hydrolyze casein, amylose or cellulose, while fewer hydrolyzed xylan (Fig. 8B).

\section{DISCUSSION}

\section{Succession in phytoplankton and bacterioplankton biomass and activity}

In early summer, large meltwater inputs mediate the establishment of a pycnocline in Disko Bay, and favourable light conditions in the surface layer trigger the development of a diatom bloom (Nielsen \& Hansen 1999). Sampling took place during the month of June, and because of advection of the water masses, the samples potentially represented water from 0 to $160 \mathrm{~km}$ away from the sampling station. It may therefore be argued that the results represent the integration of both temporal and spatial succession series. 


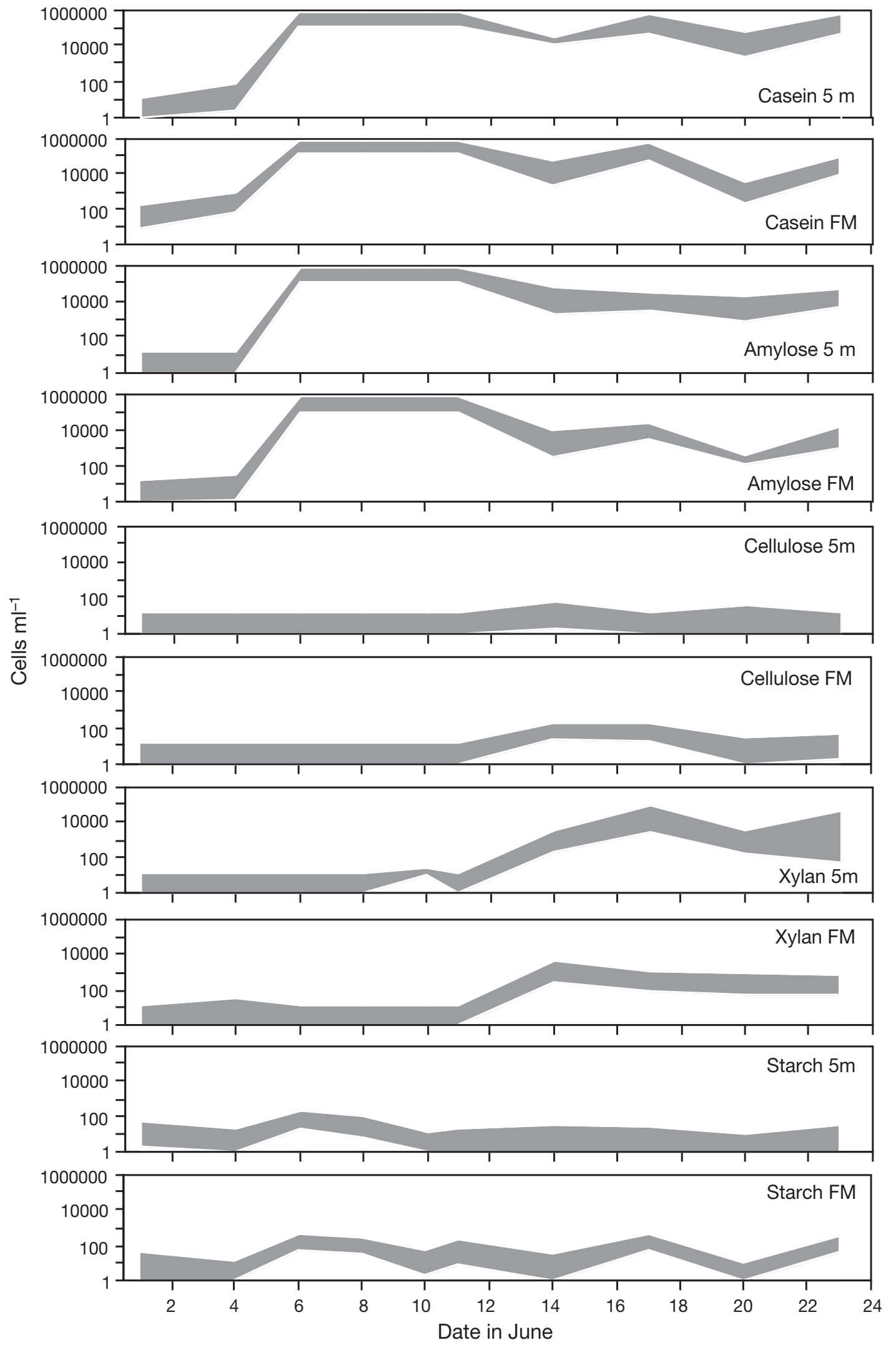

Fig. 7. Most probable number of bacteria capable of hydrolyzing different polymeric compounds. Shaded areas represent $95 \%$ confidence limits. FM: fluorescence maximum 


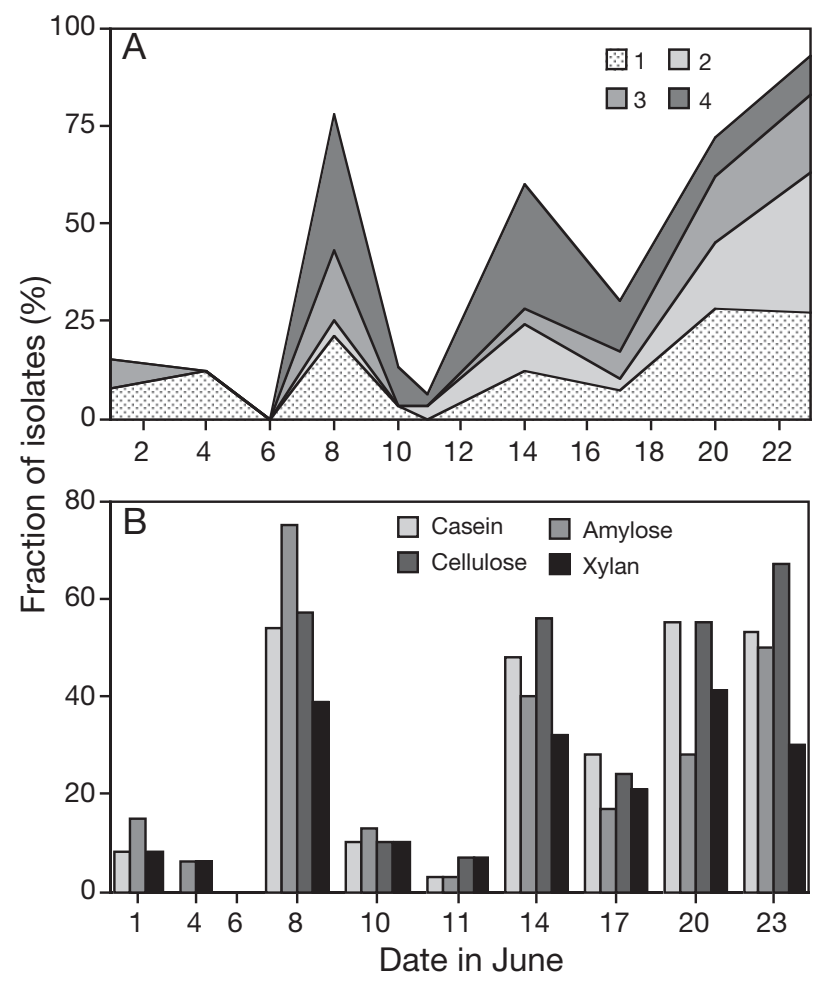

Fig. 8. Capacity of isolated bacteria to hydrolyze 4 polymeric growth substrates (casein, amylose, cellulose and xylan). (A) Cumulative fractions of isolates capable of hydrolyzing 1, 2, 3 or all 4 of the tested substrates. (B) Percentage of isolated

bacteria capable of hydrolyzing the individual substrates

However, as shown by Turner et al. (2001), the entire Disko Bay area is typically stratified during summer, with warmer temperatures and reduced salinity in the upper strata and a distinct FM at a depth of 20 to $40 \mathrm{~m}$. Thus, it is reasonable to assume that the sampled water masses were relatively homogenous and that the data reflect a temporal succession.

Sampling started at the peak or shortly after the peak of the spring bloom. Within $1 \mathrm{wk}$, the phytoplankton biomass in the intermediate cold water layer decreased from about 30 to $8 \mathrm{mg} \mathrm{chl} \mathrm{a} \mathrm{m}^{-3}$, followed by

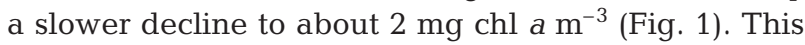
rapid decline was most likely due to the combined effects of grazing by Calanus copepods and nutrient limitation (Nielsen \& Hansen 1995).

Concurrent with the decline in diatom biomass, numbers of bacteria generally increased, although intermediate peaks in abundance were observed a few days after the initial rapid decline in chl a (Fig. 2). Bacterial abundances were within the range of values reported earlier from Disko Bay (0.3 to $1 \times 10^{6}$ cells $\mathrm{ml}^{-1}$; Møller \& Nielsen 2000) and other Arctic areas such as the Beaufort Sea $\left(2\right.$ to $6 \times 10^{5}$ cells ml ${ }^{-1}$; Garneau et al. 2006) and the Northwest Passage (1 to $7 \times$ $10^{5}$ cells ml ${ }^{-1}$; Wells \& Deming 2003). The vast majority
( 50 to $86 \%$ ) of the bacteria were HNA cells, indicating that they were metabolically active (Gasol et al. 1999, Lebaron et al. 2001). High numbers of active bacterial cells have also been observed in the western Arctic Ocean, where an average of $77 \%$ of DAPI-stained bacteria were detectable by fluorescence in situ hybridization (Garneau et al. 2006), and up to $84 \%$ were active in reducing 5-cyano-2, 3-ditoyl tetrazolium chloride (Yager et al. 2001).

Sloppy feeding by the Calanus copepods, and leakage from their fecal pellets, result in the release of dissolved organic matter (DOM) (Møller et al. 2003). Therefore, the high numbers of HNA cells and the increasing bacterial abundance most likely were due to release of labile DOM. This is supported by a study from the Alaskan Arctic, where Yager et al. (2001) observed that the heterotrophic bacterioplankton responded to an algal bloom by a doubling in cell numbers and cell size, and by an increased fraction of actively respiring cells.

At FM on 10 to 11 June, numbers of CFUs peaked at the same time as a peak in the total number of bacteria was observed (Fig. 3A). Cultivable bacteria usually only represent a small fraction of the total bacterial communities; however, since they have been shown to react rapidly to changes in substrate quality and quantity and represent the metabolically active subpopulations of the community (Ellis et al. 2003, Frette et al. 2004), the peak in culturability between 10 and 11 June was most likely due to the grazing activities by the copepods that resulted a burst in the release of labile DOM feeding the bacteria.

\section{Succession in bacterioplankton genetic diversity}

Only scant information is available on the dynamics of bacterioplankton community structures during phytoplankton blooms in the Arctic. This is in contrast to temperate waters, where several studies have addressed the coupling between bacterial community structure and function, and between phytoplankton and bacterioplankton (e.g. Larsen et al. 2004, Rink et al. 2007, Sapp et al. 2007).

Alonso-Sáez et al. (2008) demonstrated a seasonal winter-summer succession in the bacterioplankton community composition in the surface waters of Franklin Bay in the Canadian Arctic. Similarly, Yager et al. (2001) reported that the bacterial community composition shifted over a springtime algal bloom in the Chukchi Sea. However, since sampling in this case was done at different geographic locations, the existence of temporal links between bacterial community succession and bloom progression is somewhat speculative. 
In Disko Bay, the decline in chl a was accompanied by significant changes in the bacterial community structure (Fig. 4). On 8 to 11 June, concomitant with peaks in the bacterial abundance and CFUs, the community compositions at $5 \mathrm{~m}$ depth and at FM were significantly different from the composition on the other sampling days. Similarly, the species composition of the culturable bacteria changed in response to the decline in the bloom as the composition of the culturable bacteria were significantly different before and after the initial rapid decline in chl $a$ (and the peak in CFUs) (Fig. 5). In a recent study by Frette et al. (2009) it was demonstrated that availability of different dissolved species of nitrogen affected the community structure in model ecosystems. Therefore, the driving force for changing the bacterial community structure in Disko Bay was probably shifts in availability and composition of phytoplankton-derived DOM.

Based on both molecular- and cultivation-based approaches, it has been observed that Bacteroidetes group bacteria and Alphaproteobacteria appear to be numerically important members of Arctic marine bacterial assemblages (Kaneko et al. 1977, Wells \& Deming 2003, Garneau et al. 2006, Elifantz et al. 2007, Alonso-Sáez et al. 2008). Only in one study from the Arctic Ocean have Gammaproteobacteria been found to be as abundant as the Alphaproteobacteria (Bano \& Hollibaugh 2002). Surprisingly, we only observed Gammaproteobacteria amongst our collection of randomly selected isolates (Table 1), suggesting that Gammaproteobacteria dominated at least the culturable fraction of the community at FM in Disko Bay. Although successional shifts in the species composition of the isolated bacteria were observed (Fig. 5), no obvious temporal trends at the single species level were apparent, as the different species appeared and disappeared in a seemingly random manner (data not shown). A noteworthy observation was, however, that marinomonads were only found between 8 and 14 June, i.e. during the peak in CFUs.

\section{Succession in bacterioplankton functional diversity}

Changes in community enzymatic activity may be an adaptive response to changing features of the ecosystem (Misic et al. 2002). The EcoPlate metabolic fingerprints (Fig. 6) suggested that changes in the functional diversity of heterotrophic bacterioplankton occurred during the decay of the bloom, although no specific temporal trends were apparent. EcoPlates have previously been used as a tool to assess the metabolic diversity of marine bacterioplankton. For instance, Sala et al. (2008) studied the metabolic diversity of bacterioplankton in the Franklin Bay of the Beaufort Sea from early winter through spring. In the surface waters, the number of utilized substrates was highest in winter. The authors suggested that in spring, specialist phenotypes adapted to growth on freshly produced organic carbon from the phytoplankton bloom were favoured, while the winter bacterioplankton community consumed more refractory carbon sources and, hence, showed a more versatile metabolic profile.

The variation explained by the 2 principal components of our EcoPlate data (Fig. 6) was relatively low (PC1: 28\%; PC2: 12\%). This may suggest that the Biolog approach does not look at the relevant carbon sources, but it may also be an indication that several factors influenced the carbon utilization patterns of the microbial communities. Vetter \& Deming (1994) investigated extracellular enzyme (peptidase, lipase and chitobiase) activity in the Arctic Northeast Water polynya. Highest activities were observed in the upper productive water; however, no correlation between enzyme activity and temperature, carbon, nitrogen, chl $a$ and phaeopigment concentrations or bacterial abundance could be established. Thus our data and the observations by Vetter \& Deming (1994) suggest that the regulation of the community enzymatic activity is complex and involves multiple parameters.

Contrary to the EcoPlate data, temporal variation in the capacity of the bacterioplankton communities at $5 \mathrm{~m}$ and FM to hydrolyze polymeric substrates suggested that the communities became increasingly adapted to growth on refractory carbon sources as the bloom grew older (Fig. 7). The number of cells capable of hydrolyzing casein and amylose increased simultaneously with the rapid decrease in chl a (1 to 6 June), whereas the ability to hydrolyze cellulose and xylan appeared about 1 wk later. Sala \& Güde (2004) investigated the ability of bacterioplankton from Lake Constance to hydrolyze polymeric carbon sources from macrophytes and algae. In accordance with the present study, they found a succession in the ectoenzymatic activities, starting with hydrolysis of low molecular and non-structural carbohydrates followed by structural polysaccharides such as cellulose and xylan.

The observed changes in the functional characteristics of bacterioplankton during the decay of the bloom was also reflected in the population of cultivable bacteria (Fig. 8). Interestingly, at the peak in culturability on 10 to 11 June, $<13 \%$ of the isolates were able to hydrolyze the polymeric substrates. Following the rapid decline in chl $a$ and the peak in numbers of CFUs, the ability of the isolates to hydrolyze one or more of the polymeric substrates increased to almost $100 \%$. The ability to hydrolyze several polymeric carbon substrates has also been shown by Sala \& Güde (2004), who found that about half of their bacterial isolates from freshwater bacterioplankton cultures 
amended with different natural polymeric carbon sources could hydrolyze more than one of the added polymeric substrates. They suggested that a multiple hydrolytic ability would be of advantage in a system of changing inputs of organic matter as during a decaying phytoplankton bloom.

\section{Coupling between genetic and functional diversity}

Succession in the ability of the bacterioplankton communities to hydrolyze and utilize different carbon sources may be the result of shifts in the community structure and/or induction of specific enzymes. Arnosti (2008) investigated the ability of Arctic bacterioplankton communities to hydrolyze high-molecular weight carbohydrate-containing substrates. Patterns in hydrolytic activity changed over time, but a link to community diversity could not be established. Similarly, as several of our isolates had the capacity to hydrolyze more than one substrate (Fig. 8), the succession in the functional diversity of the bacterioplankton communities could be interpreted as the result of a shift in enzyme expression rather than a shift in community structure. However, since the community structure (DGGE profiles) and the species composition of the cultivable bacteria also changed in response to the decay of the bloom, a linkage between the genetic and functional diversity of the bacterioplankton is likely. This is in accordance with Murray et al. (2007), who found that the microbial community composition in seawater mesocosms influenced the hydrolytic capability of the community and that there was evidence of species-specific influences on carbon utilization on a temporal scale. The extent to which the diversity of microbial communities affects specific steps in the mineralization of DOM, however, has yet to be established (Arnosti 2008).

\section{CONCLUSIONS}

In the present study, a diverse set of bacterial parameters, including bacterial counts, numbers and diversity of CFUs, and genetic and functional fingerprints of the heterotrophic bacterial assemblages, were related to phytoplankton pigment analyses. Our results demonstrate that the bacterioplankton communities quickly responded to successional shifts in the primary producer trophic level. Also, immediately after the initial rapid decline in chl $a$, the culturability of the bacterioplankton peaked and a shift towards cells that responded immediately to increased substrate availability was observed. As the bloom grew older, a succession in the hydrolytic potential of the communities towards utilization of structural polysaccharides was observed. This change in the ability of the community to utilize different carbon sources was probably not the result of induction of specific enzymes, but rather due to changes in community structure. Thus, in Disko Bay a close link exists between the primary producers and bacterioplankton community structure and metabolic versatility.

Acknowledgements. We thank the crew of the 'Maja', and T. Juul-Pedersen, S. Gooding and B. Søborg for help with sample collection at sea. T. G. Nielsen kindly provided data for the station characterization, and S. J. Sørensen is acknowledged for making the flow cytometer available. H. Irming and T. Thane are thanked for their technical assistance, and J. Efsen Johansen for valuable advice on the enzyme assays. This work was supported by the Nordic Arctic Research Programme (grant no. 50-0033) and by a travel grant from Højgaard \& Schultz.

\section{LITERATURE CITED}

Allen AE, Howard-Jones MH, Booth MG, Frischer ME, Verity PG, Bronk DA, Sanderson MP (2002) Importance of heterotrophic bacterial assimilation of ammonium and nitrate in the Barents Sea during summer. J Mar Syst 38:93-108

Alonso-Sáez L, Sánchez O, Gasol JM, Balagué V, Pedrós-Alio C (2008) Winter-to-summer changes in the composition and single-cell activity of near-surface Arctic prokaryotes. Environ Microbiol 10:2444-2454

Andersen OGN (1981) The annual cycle of temperature, salinity, currents and water masses in Disko Bugt and adjacent waters, west Greenland. Medd Gronl 5:1-36

- Arnosti C (2008) Functional differences between Arctic seawater and sedimentary microbial communities: contrasts in microbial hydrolysis of complex substrates. FEMS Microbiol Ecol 66:343-351

Bano N, Hollibaugh JT (2002) Phylogenetic composition of bacterioplankton assemblages from the Arctic Ocean. Appl Environ Microbiol 68:505-518

Buch E (2000) A monograph on the physical oceanography of Greenland waters. Danish Meteorological Institute, Copenhagen

- Carmack EC, Macdonald RW, Jasper S (2004) Phytoplankton productivity on the Canadian Shelf of the Beaufort Sea. Mar Ecol Prog Ser 277:37-50

Christoffersen K, Lyck S, Winding A (2002) Microbial activity and bacterial community structure during degradation of microcystins. Aquat Microb Ecol 27:125-136

del Giorgio PA, David DF, Prairie YT, Planas D (1996) Flow cytometric determination of bacterial abundance in lake plankton with the green nucleic acid stain SYTO 13. Limnol Oceanogr 41:783-789

Elifantz H, Dittel AI, Cottrell MT, Kirchman DL (2007) Dissolved organic matter assimilation by heterotrophic bacterial groups in the western Arctic Ocean. Aquat Microb Ecol 50:39-49

Ellis RJ, Morgan P, Weightman AJ, Fry JC (2003) Cultivationdependent and -independent approaches for determining bacterial diversity in heavy-metal-contaminated soil. Appl Environ Microbiol 69:3223-3230

> Frette L, Johnsen K, Jørgensen NOG, Nybroe O, Kroer K (2004) Functional characteristics of culturable bacterioplankton from marine and estuarine environments. Int Microbiol 7:219-227 
Frette L, Jørgensen NOG, Nybroe O, del Giorgio P, Kroer K (2009) Effect of availability of nitrogen compounds on community structure of aquatic bacteria in model systems. Microb Ecol 57:104-116

Garneau MÉ, Vincent WF, Laura AS, Gratton Y, Lovejoy C (2006) Prokaryotic community structure and heterotrophic production in a river-influenced coastal arctic ecosystem. Aquat Microb Ecol 42:27-40

Gasol JM, Zweifel UL, Peters F, Fuhrman JA, Hagström Å (1999) Significance of size and nucleic acid content heterogeneity as measured by flow cytometry in natural planktonic bacteria. Appl Environ Microbiol 65: 4475-4483

> Howard-Jones MH, Ballard VD, Allen AE, Frischer ME, Verity PG (2002) Distribution of bacterial biomass and activity in the marginal ice zone of the central Barents Sea during summer. J Mar Syst 38:77-91

Juul-Pedersen T, Nielsen TG, Michel C, Møller EF and others (2006) Sedimentation following the spring bloom in Disko Bay, West Greenland, with special emphasis on the role of copepods. Mar Ecol Prog Ser 314:239-255

Kaneko T, Atlas RM, Krichevsky M (1977) Diversity of bacterial populations in the Beaufort Sea. Nature 270:596-599

Kirchman DL, Elifantz H, Dittel AI, Malmstrom RR, Cottrell MT (2007) Standing stocks and activity of Archaea and Bacteria in the western Arctic Ocean. Limnol Oceanogr 52:495-507

Larsen A, Flaten GAF, Sandaa RA, Castberg $\mathrm{T}$ and others (2004) Spring phytoplankton bloom dynamics in Norwegian coastal waters: microbial community succession and diversity. Limnol Oceanogr 49:180-190

> Lebaron P, Servais P, Agogué H, Courties C, Jou F (2001) Does the high nucleic acid content of individual bacterial cells allow us to discriminate between active cells and inactive cells in aquatic systems? Appl Environ Microbiol 67:1775-1782

Malmstrom RR, Straza TRA, Cottrell MT, Kirchman DL (2007) Diversity, abundance, and biomass production of bacterial groups in the western Arctic Ocean. Aquat Microb Ecol 47:45-55

> Misic C, Povero P, Fabiano M (2002) Ectoenzymatic ratios in relation to particulate oraganic matter distribution (Ross Sea, Antarctica). Microb Ecol 44:224-234

Møller EF, Nielsen TG (2000) Plankton community structure and carbon cycling off the western coast of Greenland, with emphasis on sources of DOM for the bacterial community. Aquat Microb Ecol 22:13-25

> Møller EF, Thor P, Nielsen TG (2003) Production of DOC by Calanus finmarchicus, C. glacialis and C. hyperboreus through sloppy feeding and leakage from fecal pellets. Mar Ecol Prog Ser 262:185-191

Müller-Niklas G, Herndl GJ (1996) Dynamics of bacterioplankton during a phytoplankton bloom in the high Arctic waters of the Franz-Joseph Land archipelago. Aquat Microb Ecol 11:111-118

Murray AE, Arnosti C, De La Rocha CL, Grossart HP, Passow U (2007) Microbial dynamics in autotrophic and heterotrophic seawater mesocosms. II. Bacterioplankton community structure and hydrolytic enzyme activities. Aquat Microb Ecol 49:123-141

Editorial responsibility: Hans-Georg Hoppe, Kiel, Germany
Muyzer G, de Waal EC, Uitterlinden AG (1993) Profiling of complex microbial populations by denaturing gradient gel electrophoresis analysis of polymerase chain reactionamplified genes coding for 16S rRNA. Appl Environ Microbiol 59:695-700

Nielsen TG, Hansen B (1995) Plankton community structure and carbon cycling on the western coast of Greenland during and after the sedimentation of a diatom bloom. Mar Ecol Prog Ser 125:239-257

Nielsen TG, Hansen BW (1999) Plankton community structure and carbon cycling on the western coast of Greenland during the stratified summer situation. I. Hydrography, phytoplankton and bacterioplankton. Aquat Microb Ecol 16:205-216

Riemann L, Winding A (2001) Community dynamics of freeliving and particle-associated bacterial assemblages during a freshwater phytoplankton bloom. Microb Ecol 42:274-285

Rink B, Seeberger S, Martens T, Duerselen CD, Simon M, Brinkhoff T (2007) Effects of phytoplankton bloom in a coastal ecosystem on the composition of bacterial communities. Aquat Microb Ecol 48:47-60

Sala MM, Güde H (2004) Ectoenzymatic activities and heterotrophic bacteria decomposing detritus. Arch Hydrobiol 160:289-303

Sala MM, Terrado R, Lovejoy C, Unrein F, Pedrós-Alió C (2008) Metabolic diversity of heterotrophic bacterioplankton over winter and spring in the coastal Arctic Ocean. Environ Microbiol 10:942-949

Sapp M, Wichels A, Wiltshire KH, Gerdts G (2007) Bacterial community dynamics during the winter-spring transition in the North Sea. FEMS Microbiol Ecol 59:622-637

Turner JT, Levinsen H, Nielsen TG, Hansen BW (2001) Zooplankton feeding ecology: grazing on phytoplankton and predation on protozoans by copepod and barnacle nauplii in Disko Bay, West Greenland. Mar Ecol Prog Ser 221:209-219

Vetter YA, Deming JW (1994) Extracellular enzyme activity in the Arctic Northeast Water polynya. Mar Ecol Prog Ser $114: 23-34$

Wells LE, Deming JW (2003) Abundance of Bacteria, the Cytophaga-Flavobacterium cluster and Archaea in cold oligotrophic waters and nepheloid layers of the Northwest Passage, Canadian Archipelago. Aquat Microb Ecol 31: $19-31$

Willumsen PA, Johansen JE, Karlson U, Hansen BM (2005) Isolation and taxonomic affiliation of N-heterocyclic aromatic hydrocarbon-transforming bacteria. Appl Microbiol Biotechnol 67:420-428

Wilmotte A, Van der Auwera G, De Wachter R (1993) Structure of the $16 \mathrm{~S}$ ribosomal RNA of the thermophilic cyanobacterium chlorogloeopsis HTF ('mastigocladus laminosus $\mathrm{HTF}^{\prime}$ ) strain PCC7518, and phylogenetic analysis. FEBS Lett 317:96-100

Yager PL, Connelly TL, Mortazavi B, Bano N, Bauer JE, Opsahl S, Hollibaugh JT (2001) Dynamic bacterial and viral response to an algal bloom at subzero temperatures. Limnol Oceanogr 46:790-801

Zobell C (1946) Marine microbiology; a monograph on hydrobacteriology. Chronica Botanica, Waltham, MA

Submitted: September 12, 2009; Accepted: February 17, 2010 Proofs received from author(s): April 15, 2010 